\title{
MENGENAL JENIS-JENIS CACING LAUT DAN PELUANG BUDIDAYANYA UNTUK PENYEDIAAN PAKAN ALAMI DI PEMBENIHAN UDANG
}

\author{
Rasidi \\ Pusat Penelitian dan Pengembangan Perikanan Budidaya \\ Jl. Ragunan 20 Pasar Minggu, Jakarta Selatan 12540 \\ E-mail: rasidi_clp@yahoo.com
}

\section{ABSTRAK}

Cacing laut merupakan salah satu jenis pakan alami yang banyak digunakan sebagai pakan induk udang di pembenihan udang. Jenis-jenis cacing laut yang dimanfaatkan sebagai pakan alami induk udang di pembenihan udang antara lain dari famili Nereidae dan Eunicidae. Famili Nereidae terdiri atas Nereis sp., Namalycastis, Perinereis nuntia. Famili Eunicidae terdiri atas Marphysa sp.-1, dan Marphysa sp.-2. Berbagai jenis cacing laut tersebut mempunyai nama lokal yang berbeda-beda di beberapa wilayah seperti di Kabupaten Serang, Cilacap, Situbondo, dan Barru. Masyarakat setempat memperoleh cacing laut tersebut dari penangkapan di alam antara lain di kawasan mangrove, tambak, dan pantai. Pembenihan udang sebagai pengguna sangat mengharapkan cacing laut dapat dibudidayakan sehingga kebutuhan pakan alami tidak tergantung dari hasil penangkapan saja. Pembenihan udang telah siap menerima produksi cacing laut dari hasil budidaya jika cacing laut berhasil dikembangkan, hal ini menjadi peluang pasar yang menjanjikan sehingga potensi dan peluang sebagai salah satu komoditas penting untuk memenuhi kebutuhan pakan alami dalam industri akuakultur terpenuhi.

\section{KATA KUNCI : cacing laut, induk udang, pakan} alami, dan pembenihan udang

\section{PENDAHULUAN}

Pembenihan udang dalam kegiatan proses produksi benih udang memanfaatkan beberapa jenis pakan alami antara lain cacing laut, kekerangan, dan cumi-cumi. Jenisjenis pakan alami tersebut diperoleh dari penangkapan di alam. Pemanfaatan pakan alami tersebut disebabkan kandungan gizi yang terkandung di dalamnya dipercaya dapat menstimulasi sistem bioreproduksi udang. Di antara jenis pakan alami tersebut yang paling berperan penting dalam bioreproduksi udang adalah cacing laut. Cacing laut bagi kebanyakan orang merupakan binatang yang menjijikkan, namun di balik semua itu ternyata cacing laut mempunyai keunggulan dan mampu memenuhi kebutuhan nutrisi induk udang (Yuwono, 2005). Keberhasilan cacing laut sebagai pakan alami induk udang telah banyak diteliti khususnya dalam proses pematangan gonad dan pemijahan induk udang (Wouters et al., 2001; Coman et al., 2007; Meunpol et al., 2007; Kian et al., 2004; Nguyen et al., 2011).

Produksi benih udang selama ini dihasilkan dari pembenihan udang yang tersebar di pusat-pusat pembenihan baik skala besar maupun skala kecil. Kegiatan produksi benih ini menggunakan beberapa jenis pakan alami baik untuk induk dan naupli. Salah satu jenis pakan alami yang banyak digunakan sebagai pakan induk udang adalah cacing laut. Di habitat aslinya cacing laut sebenarnya mempunyai fungsi yang penting. Dalam rantai makanan cacing laut merupakan pakan alami bagi hewan-hewan air yang ada di lingkungannnya misalnya udang dan ikan. Selain itu, cacing laut dalam bidang ekologi dapat juga dijadikan bioindikator kualitas perairan (Tomassetti \& Porrello, 2005).

Walaupun demikian cacing laut yang berasal dari alam mempunyai risiko membawa penyakit dan zat-zat toksik berbahaya yang dapat menular ke induk udang (Vijayan et al., 2005; Morales et al., 2008). Oleh karena itu, diperlukan budidaya cacing laut, karena dengan budidaya lingkungan dapat dikontrol sehingga produk hasil budidaya lebih aman dibandingkan dengan hasil penangkapan di alam.

Untuk menuju budidaya tentunya diawali dari pengenalan spesies yang mungkin dapat dibudidayakan. 
Tulisan ini bertujuan untuk mengenal beberapa jenis cacing laut yang dimanfaatkan di pembenihan udang. Dalam tulisan ini juga akan disajikan potensi budidaya dan perkembangan budidaya cacing laut di luar negeri yang sudah dikerjakan dan berkembang pada skala industri.

\section{Jenis-jenis Cacing Laut}

Cacing laut termasuk dalam filum Annelida kelas Polychaeta (Fauchald, 1977). Polychaeta berasal dari bahasa latin yang terdiri atas Poly dan chetae, poly artinya banyak sedangkan chetae merupakan bagian yang menyerupai rambut yang terletak di pinggir kanan dan kiri badan cacing. Ciri khas dari Polychaeta adalah banyaknya chetae yang terlihat seperti kaki-kaki di seluruh badannya.

Anggota filum Annelida yang telah teridentifikasi sekitar 9.000 spesies dan sebagian besar terdiri atas Polychaeta sebanyak 8.000 spesies. Karena banyaknya spesies Polychaeta sehingga untuk membedakannya diperlukan keahlian antara spesies yang satu dengan yang lainnya. Bagian-bagian badan utama cacing laut pembeda famili dan

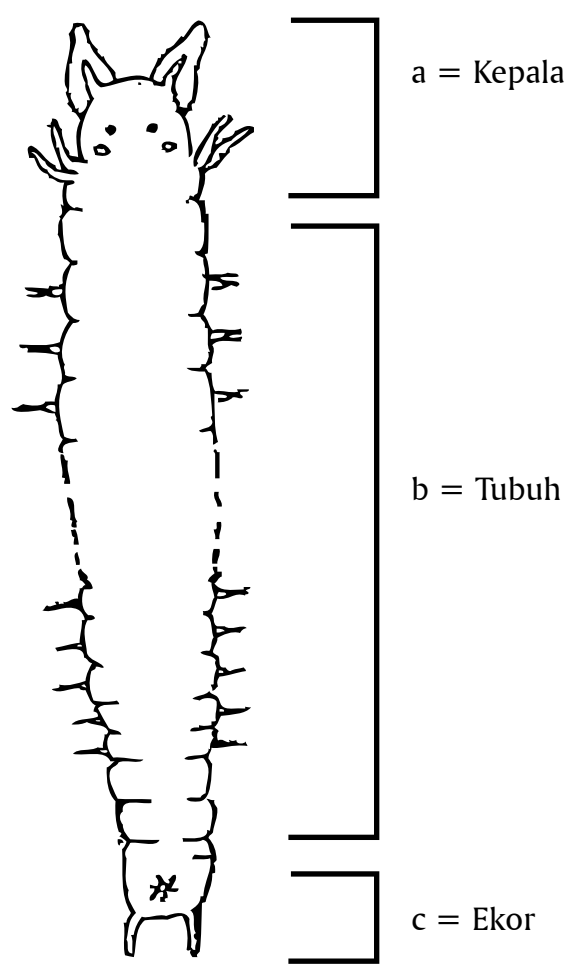

Sumber: $\quad$ Fauchald (1977).

Gambar 1. Morfologi cacing laut Polychaeta genus adalah prostomium, peristomium, farink, parapodia, dan setae. Morfologi umum cacing laut terdiri atas kepala, badan, dan ekor (Fauchald, 1977) disajikan pada Gambar 1.

Cacing laut yang dimanfaatkan di beberapa daerah sentra pembenihan udang ternyata mempunyai jenis yang berbeda-beda. Secara umum masyarakat mengenal cacing laut dengan nama lokal masing-masing daerah. Sebagian masyarakat mengenal cacing laut semua jenis dengan nama cacing Nereis. Walaupun jika ditelusuri lebih lanjut cacing laut dari beberapa daerah tersebut ternyata mempunyai nama ilmiah yang berbeda. Jenis-jenis yang dimanfaatkan sebagai pakan alami induk udang antara lain dari famili Eunicidae dan Nereidae. Famili Eunicidae terdiri atas Marphysa sp.-1, Marphysa sp.-2, dan Marphysa sanguinea Famili Nereidae terdiri atas Nereis sp., Namalycastis sp., Perinereis nuntia (Rasidi, 2012). Jenis-jenis cacing laut yang ditemukan di beberapa pusat pembenihan udang di Kabupaten Serang, Cilacap, Situbondo, dan Barru disajikan pada Gambar 2-7.

Cacing Nereis sp. lebih banyak dikenal masyarakat lokal dan dijadikan nama umum untuk semua jenis cacing laut yang dimanfaatkan di pembenihan udang, walaupun setelah diidentifikasi nama ilmiah cacing laut tersebut belum tentu Nereis sp. Hal ini wajar karena sangat sulit membedakan jenisnya secara visual, untuk membedakannya harus dilakukan pengamatan menggunakan mikroskop dan keahlian identifikasi.

\section{Potensi dan Status Budidaya Cacing Laut di Indonesia}

Cacing laut sebenarnya mempunyai potensi untuk dibudidayakan di Indonesia. Potensi tersebut dapat dilihat dari banyaknya pembenihan udang yang memanfaatkannya sebagai pakan induk di beberapa sentra pembenihan udang di Indonesia antara lain di wilayah Kabupaten Serang, Cilacap, Situbondo, dan Barru (Rasidi, 2012). Cacing laut tersebut ternyata masih harus didatangkan dari luar daerah masing-masing misalnya pembenihan udang di Situbondo memperoleh cacing laut dari penangkap lokal dari Situbondo, Banyuwangi, dan Tuban. Pembenihan udang di Cilacap harus dikirim juga dari Tuban. Pembenihan udang di Gondol juga mendapatkan cacing laut dari Banyuwangi. Hal ini disebabkan belum adanya penangkap cacing di 

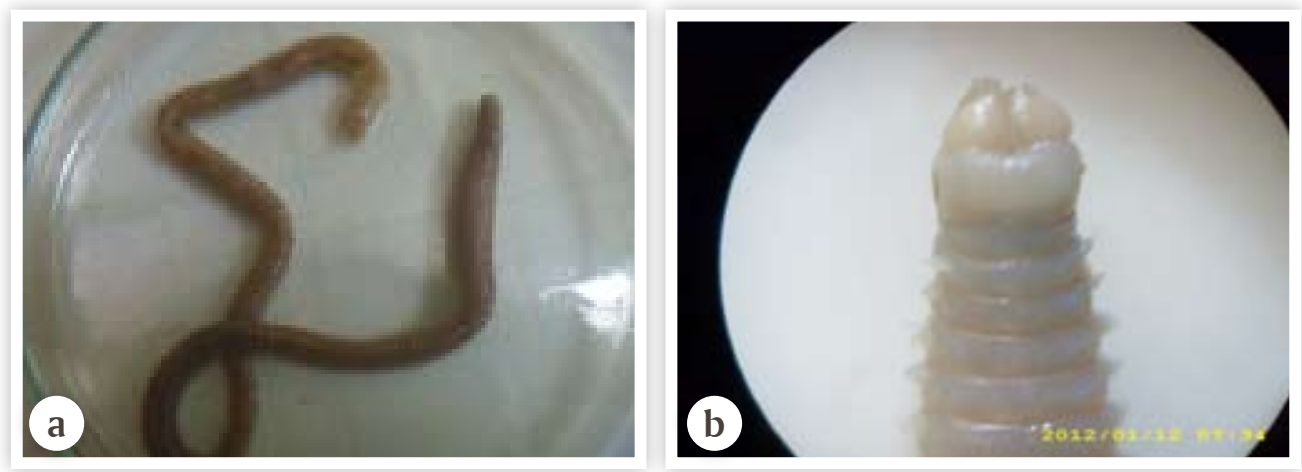

Gambar 2. Marphysa sp.-1 (skala $1 \mathrm{~cm}$ ) (a); morfologi kepala Marphysa sp.-1 (20x) (b)
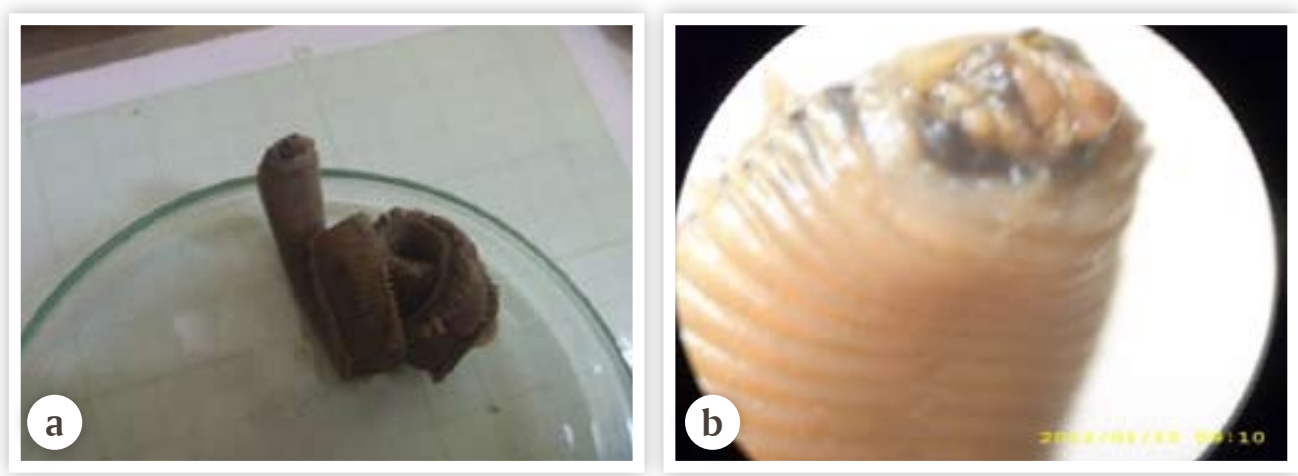

Gambar 3. Marphysa sp.-2 (skala $1 \mathrm{~cm}$ ) (a); morfologi kepala Marphysa sp.-2 (20x) (b)
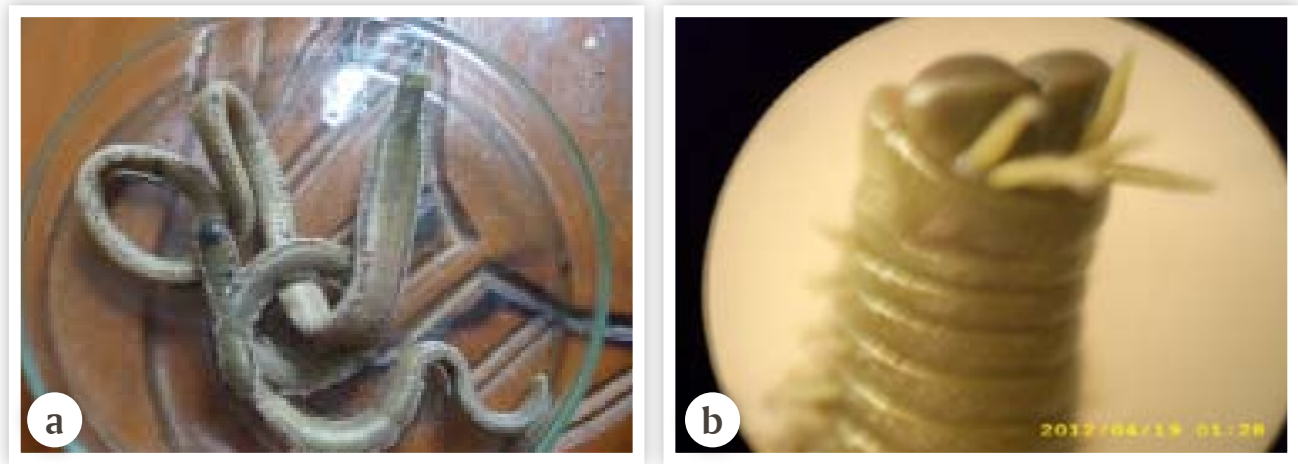

Gambar 4. Marphysa sanguinea (skala $1 \mathrm{~cm}$ ) (a); morfologi kepala Marphysa sanguinea $(20 \mathrm{x})(\mathrm{b})$
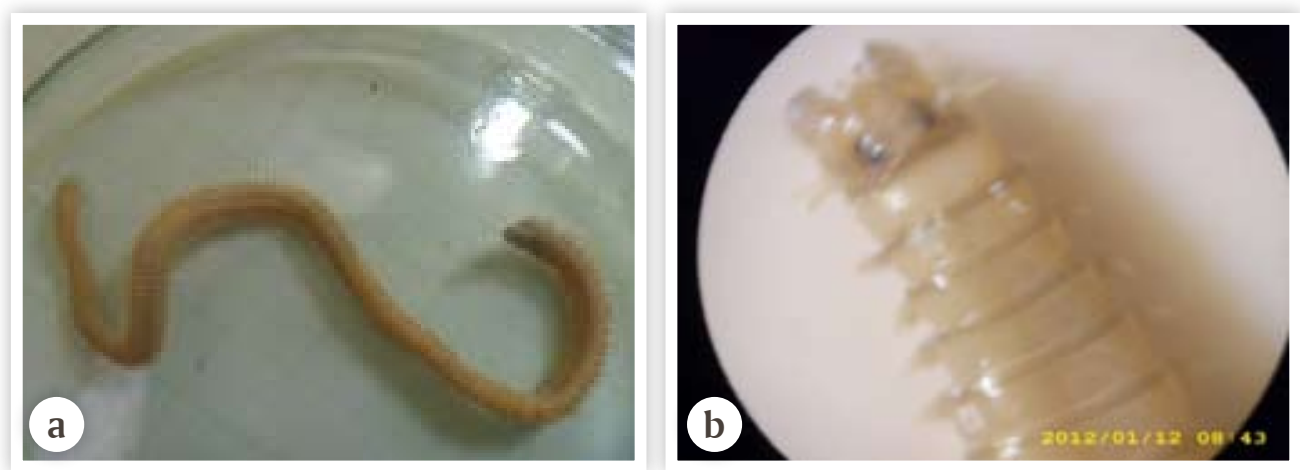

Gambar 5. Perinereis nuntia (skala $1 \mathrm{~cm}$ ) (a); morfologi kepala Perinereis nuntia (20x) (b) 
Gambar 6. Namalycastis sp. (skala $1 \mathrm{~cm}$ ) (a); morfologi kepala Namalycastis sp. (20x) (b)

Gambar 7. Nereis sp. (skala $1 \mathrm{~cm}$ ) (a); morfologi kepala Nereis sp. (20x) (b)
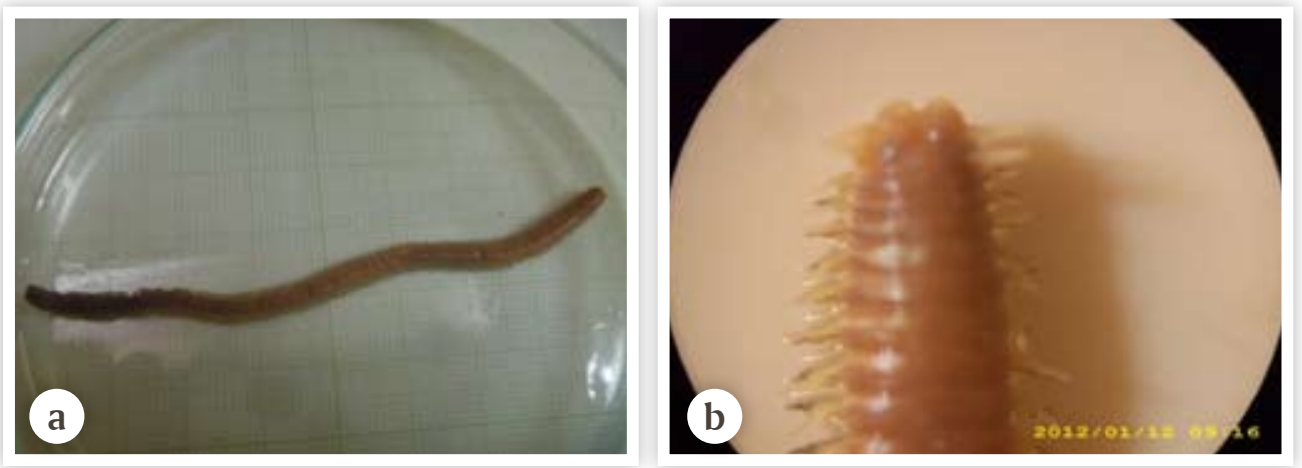

\section{Gambar 8. Lokasi}
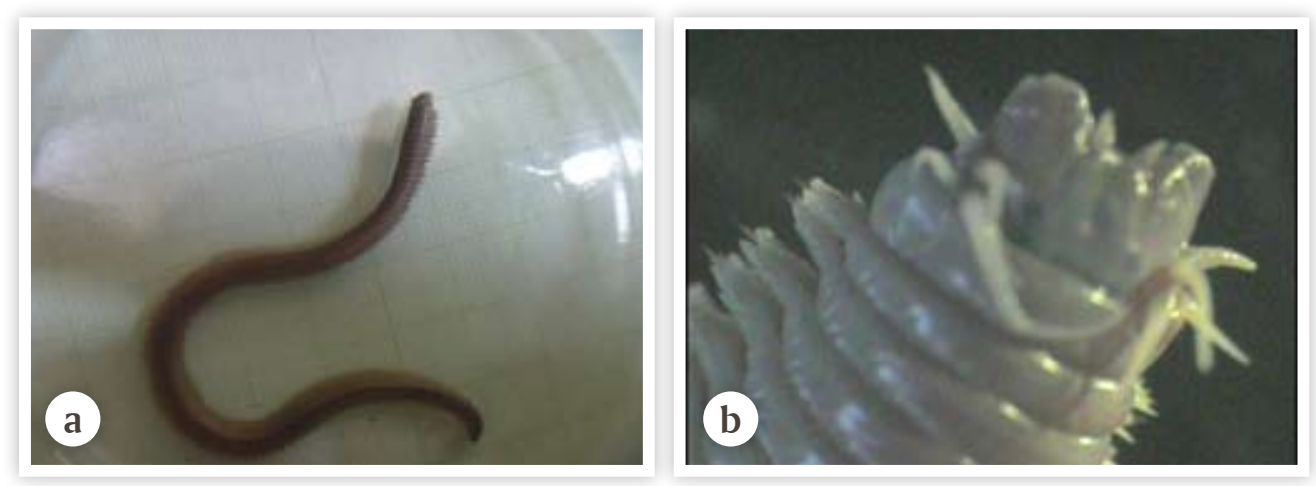

\section{penangkapan
cacing laut (a) dan
pemanfaatan cacing
sebagai umpan \\ penangkapan
cacing laut (a) dan
pemanfaatan cacing
sebagai umpan \\ penangkapan
cacing laut (a) dan
pemanfaatan cacing
sebagai umpan \\ penangkapan
cacing laut (a) dan
pemanfaatan cacing
sebagai umpan memancing (b)}
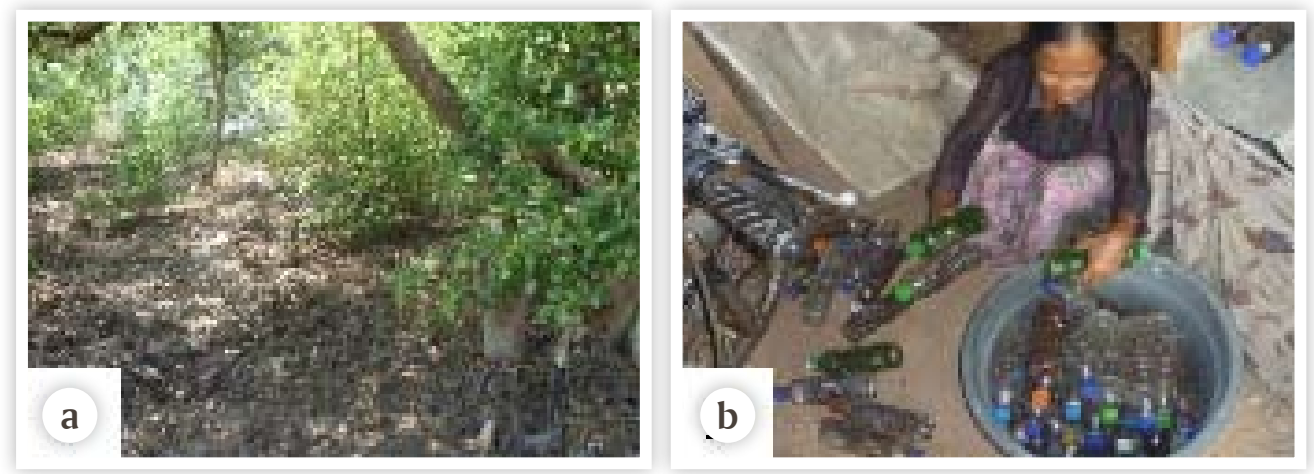

masing-masing wilayah. Keadaan ini sebenarnya menjadi peluang pemasaran produk cacing laut hasil budidaya ke depan. Jika di luar negeri saja cacing laut dapat dikembangkan kemungkinan besar di Indonesia juga dapat dibudidayakan.

Pembenihan udang akan siap menerima produksi hasil budidaya cacing laut ini jika dapat dikembangkan di Indonesia. Jika dilihat dari permintaan pasar, pembenihan udang yang tersebar di wilayah di Jawa maupun luar Jawa selama ini banyak yang memanfaatkannya sebagai salah satu pakan alami untuk induk udang.

Selain untuk pakan induk udang, cacing laut juga dapat dimanfaatkan sebagai umpan memancing. Berdasarkan hasil survai di Serang, Banten pedagang cacing laut dapat menjual cacing laut berkisar 10-20 botol pada hari-hari biasa jika pada akhir pekan akan lebih banyak lagi. Harga cacing laut untuk umpan memancing sebesar Rp 5.000,--/botol. Jika dalam satu hari dapat menjual cacing laut sebanyak 10 botol dapat terkumpul Rp 50.000,-/hari. Hal ini dapat dijadikan peluang pekerjaan cukup bagus.

Harga cacing laut di beberapa daerah sentra pembenihan udang di Serang, Cilacap, Situbondo, dan Baru berkisar Rp 22.000,- - Rp 50.000,- dengan rata-rata Rp 32.315,-/ $\mathrm{kg}$ (Rasidi, 2012). Harga cacing laut dari penangkapan di alam masih jauh lebih murah, jika dibandingkan dengan harga cacing laut hasil budidaya harganya mencapai US\$ 
40 (Anonim, 2007). Tingginya harga cacing laut produksi budidaya tersebut disebabkan sudah ada jaminan bebas penyakit.

Pemenuhan kebutuhan pakan alami untuk pakan benih ikan dan udang di Indonesia seperti halnya Artemia yang masih harus diimpor dari luar negeri, impor cacing laut juga sudah mulai merambah negeri ini, walaupun jumlahnya masih relatif kecil. Berdasarkan data dari Direktorat Jenderal Perikanan Budidaya pada tahun 2012 impor cacing laut beku (frozen Polychaeta) sebesar 2.550 ton dengan nilai US\$ 17.973,80 (Anonim, 2012). Hal ini menunjukkan cacing laut telah menjadi salah satu komoditas penting di dalam dunia akuakultur sehingga harus impor dari luar negeri. Impor cacing laut dilakukan karena di Indonesia budidaya cacing laut belum berkembang.

Kendala budidaya cacing laut di Indonesia belum berkembang antara lain cacing laut belum dianggap sebagai komoditas penting sehingga perhatian akan komoditas ini juga belum ada. Akibatnya data produksi cacing laut hasil penangkapan di beberapa sentra pembenihan udang juga tidak terekam dengan baik, walaupun data-data hasil penangkapan tersebut sangat penting untuk menentukan status produksi cacing laut ke depan.

Berbeda dengan budidaya cacing tanah yang telah berkembang, budidaya cacing laut di Indonesia masih pada taraf penelitian. Penelitian budidaya cacing laut sebenarnya juga telah dirintis di Indonesia sejak tahun 2000-an. Pembenihan cacing laut jenis cacing lur (Dendronereis pinnaticirris) telah berhasil dilakukan (Yuwono et al., 2002; Yuwono, 2003). Penelitian dari berbagai aspek budidaya untuk jenis-jenis cacing laut yang lain, yang dimanfaatkan di pembenihan udang di masing-masing daerah masih sangat diperlukan sehingga budidaya cacing laut dapat berkembang di Indonesia sebagai salah satu upaya penyediaan pakan alami untuk induk udang.

\section{Perkembangan Budidaya Cacing Laut Skala Industri}

Secara umum beberapa jenis cacing laut telah berhasil dikembangkan skala industri di beberapa negara, misalnya Nereis sp. telah berhasil dibudidayakan oleh perusahaan Sea Bait Ltd. (Inggris) yang telah mengembangkannya sejak
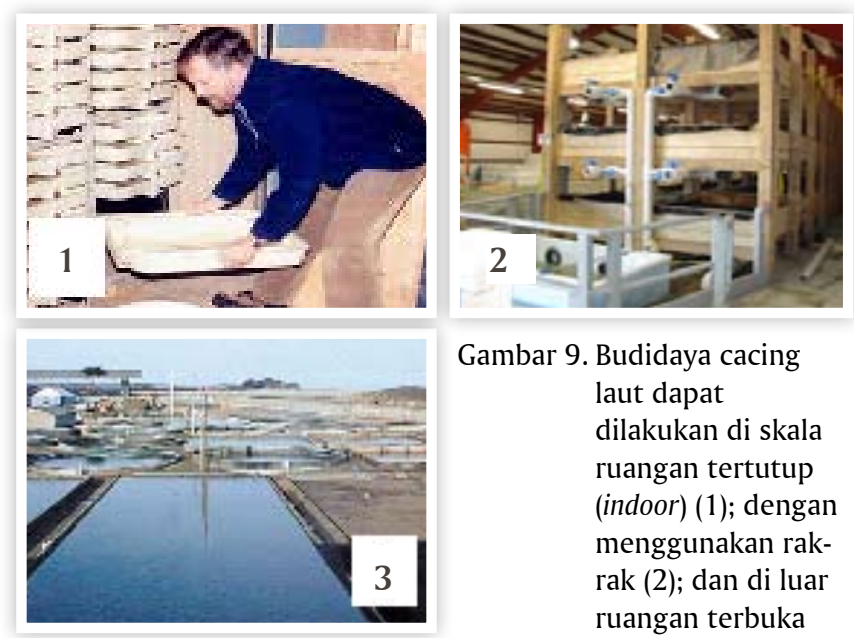

\section{Gambar 9. Budidaya cacing} laut dapat dilakukan di skala ruangan tertutup (indoor) (1); dengan menggunakan rakrak (2); dan di luar ruangan terbuka (outdoor) (3)
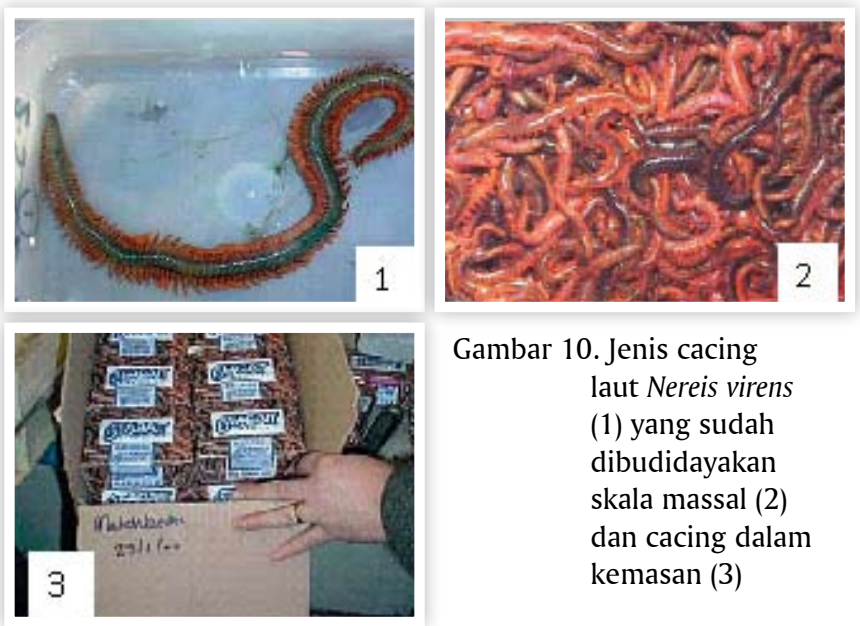

Gambar 10. Jenis cacing laut Nereis virens (1) yang sudah dibudidayakan skala massal (2) dan cacing dalam kemasan (3)

tahun 1985. Di Inggris telah berhasil mengembangkan budidaya Nereis virens skala massal. Budidaya dilakukan di ruangan (indoor) dan outdoor untuk pembesaran secara intensif dengan menggunakan sistem teknologi resirkulasi (Gambar 8a-c) dan pengemasan telah dilakukan untuk dikirim ke konsumen di berbagai negara (Gambar 9). Jika di luar negeri cacing laut dapat dikembangkan kemungkinan besar di Indonesia juga dapat dibudidayakan.

\section{KESIMPULAN}

Jenis-jenis cacing laut yang dimanfaatkan sebagai pakan induk terdiri atas 2 famili dan 6 jenis. Semua jenis tersebut telah dimanfaatkan sebagai salah satu pakan alami untuk induk udang di pembenihan udang. Cacing laut mempunyai potensi untuk dikembangkan melalui budidaya. Cacing laut masih memerlukan berbagai penelitian untuk menuju budidayanya di Indonesia seperti yang telah dikembangkan 
di luar negeri. Budidaya cacing laut dapat dijadikan salah satu alternatif peluang penelitian dan usaha yang masih terbuka lebar untuk penyediaan pakan alami di pembenihan udang.

\section{DAFTAR ACUAN}

Anonim. 2007. Polychaetes: SPF super worms. Feed Technology Update, 2(1): 41.

Anonim. 2012. Statisik impor pakan perikanan budidaya tahun 2012. Direktorat Jenderal Perikanan Budidaya (tidak dipulikasi).

Coman, G.J., Arnold, S.J., Callaghan, T.R., \& Preston, N.P. 2007. Effect of two maturation diet combinations on reproductive performance of domesticated Penaeus monodon. Aquaculture, 263: 75-83.

Fauchald, K. 1977. The Polychaeta worms definition and keys to the orders, famili and genera. Natural History Museum. Los Angeles, 198 pp.

Kian, A.Y.S., Mustafa, S., \& Rahman, R.A. 2004. Broodstock condition and egg quality in tiger prawn, Penaeus monodon, resulting from feeding bioencapsulated live prey. Aquaculture International, 12: 423-433.

Meunpol, O., Iam-Pai, S., Suthikrai, W., \& Piyatiratitivorakul, S. 2007. Identification of progesterone and 17á hydroxyprogesterone in polychaetes (Perinereis sp.) and the effects of hormone extracts on penaeid oocyte development in vitro. Aquaculture, 270: 485-492.

Morales-Caselles, C., Ramos, J., Riba, I., \& DelValls, T.Á. 2008. Using the polychaete Arenicola marina to determine toxicity and bioaccumulation of PAHS bound to sediments. Environmnetal Monitoring Assessment, 142: 219-226.
Nguyen, B.T., Koshio, S., Sayikama, K., Ishikawa, M., Yokoyama, S., \& Kader, M.A. 2011. Effects of polychaete extracts on reproductive performance of kuruma shrimp, Marsupenaeus japonicus Bate.-Part II. Ovarian maturation and tissue lipid compositions, Aquaculture, doi: 10.1016/j.aquaculture.2011.11.038.

Rasidi. 2012. Pertumbuhan, sintasan, dan kandungan nutrisi cacing Polychaeta Nereis sp. yang diberi jenis pakan berbeda dan kajian pemanfaatan Polychaeta oleh masyarakat sebagai pakan induk di pembenihan udang. Tesis. Fakultas MIPA Program Pascasarjana Biologi. Universitas Indonesia. Depok.

Tomassetti, P. \& Porrello, S. 2005. Polychaetes as indicators of marine fish farm organic enrichment. Aquaculture International, 13: 109-128.

Vijayan, K.K., Stalin Raj, V., Balasubramanian, C.P., Avalandi, S.V., Thillai Sekhar, V., \& Santiago, T.C. 2005. Jurnal Diseases of aquatic organisms, 63: 107-111.

Wouters, R., Lavens, P., Nieto, J., \& Sorgeloos, P. 2001. Penaeid shrimp broodstock nutrition: an updated review on research and development. Aquaculture, 202: 1-21.

Yuwono, E., Haryadi, B., Susilo, U., Sahri, A., \& Sugiharto. 2002. Fertilisasi serta pemeliharaan larva dan juvenil sebagai upaya pengembangan teknik budidaya cacing lur. Biosfera, 19(3): 20-26.

Yuwono, E. 2003. Studi aspek fisiologi untuk aplikasi dalam budidaya cacing lur (Nereis sp.). Sains Akuatik, hlm. 66-74.

Yuwono, E. 2005. Kebutuhan nutrisi Crustacea dan potensi cacing lur (Nereis, Polychaeta) untuk pakan udang. Jurnal Pembangunan Pedesaan, V(1): 42-49. 